\title{
Fiber Content and Mineral Composition of the Finger Millet of the Oasis of Gabes Tunisia
}

\author{
Khouloud BACHAR ${ }^{1}$, Elhem MANSOUR ${ }^{1}$, Abdennaceur Ben Khaled ${ }^{1}$, Mabrouka ABID ${ }^{1}$, Mansour HADDAD ${ }^{1}$, \\ Leila BEN YAHYA ${ }^{1}$, Nacer EL JARRAY ${ }^{2} \&$ Ali FERCHICHI ${ }^{1}$ \\ ${ }^{1}$ Aridoculture and Oases Crops Laboratory, Institute of Arid Lands, ElFjé Medenine, Tunisia \\ ${ }^{2}$ Laboratory of Wildlife Breeding, Institute of Arid Lands, ElFjé Medenine, Tunisia \\ *Correspondence: Khouloud Bachar, Aridoculture and Oases Crops Laboratory, Institute of Arid Lands, ElFjé \\ Medenine, Tunisia. Tel: 216-2071-4056. E-mail: khouloud_bachar@yahoo.fr
}

Received: September 21, 2012 Accepted: October 9, 2012 Online Published: January 15, 2013

doi:10.5539/jas.v5n2p219 URL: http://dx.doi.org/10.5539/jas.v5n2p219

\begin{abstract}
Despite the decline in the areas reserved for the cultivation of the finger millet (Eleusine coracana $\mathrm{L}$.) in the coastal oasis, this specie had occupied an important place in the diet of the inhabitants of the south of Tunisia and especially the region of Gabes. To contribute to a better knowledge of this plant in the oasis of Gabes, mineral and fiber characterizations were performed for 30 samples collected from four oases of Gabes. For each sample 11 nutrients: ( $\mathrm{Na}, \mathrm{K}, \mathrm{P}, \mathrm{Ca}, \mathrm{Mg}$ and $\mathrm{N}$ ), the crude protein, the neutral detergent fiber, the acid detergent fiber, the crude fiber and ash contents, were studied. Results of minerals analysis showed that calcium and magnesium were the most concentrated nutrients in all studied accessions $(189.93-1272.36 \mathrm{mg} / 100 \mathrm{~g}$ and $84.71-567.45 \mathrm{mg} / 100 \mathrm{~g}$ respectively), followed by potassium $(11.24-284.7 \mathrm{mg} / 100 \mathrm{~g})$, sodium $(13.73-42.47$ $\mathrm{mg} / 100 \mathrm{~g}$ ) and phosphorus (2.208-11.033 mg/100g). Acid detergent fiber, neutral detergent fiber, crude fiber and ash average contents of the accessions were respectively higher than $30.58,12.65,4.01$ and $3.2 \%$ of dry matter of the finger millet.
\end{abstract}

Keywords: finger millet, chemical composition, crude protein, the neutral detergent fiber, the acid detergent fiber

\section{Introduction}

Finger millet is an annual, tufted grass and varies in height from as little as $25 \mathrm{~cm}$ up to more than $120 \mathrm{~cm}$. It tillers at a population of less than 10 plants per square meter (Johnson, 1968).

It accounts for $8 \%$ of the area and $11 \%$ of production of all millets in the world (Bennetzen, Dida, Manyera, \& Devos, 2003). It is grown in over 25 countries in Africa (East and South) and Asia (Middle East and Far East), mainly for grain (International Centre for Agricultural Research in the Semi Arid Tropics [ICRISAT], 1997). For several years, this species was considered one of the most important crops grown in the oasis of Gabes. It had prominently occupied an important place in the oasis. The finger millet remains largely unknown and unstudied in oasis conditions and it is threatened by extinction, despite it's important role in these ecosystems.

Finger millet was used for the preparation of some very popular dishes (polenta and couscous) and as a medicinal herb to combat certain Child health diseases such as Ascaris. Watt and Breyer-Brandwijk (1962) reported that the plant of finger millet is diaphoretic, diuretic, and vermifuge and the leaf juice has been given to women in childbirth. In India, finger millet is used as folk remedy for leprosy, liver disease (Watt \& Breyer-Brandwijk, 1962), measles, pleurisy, pneumonia, and small pox (Duke \& Wain, 1981).

Finger millet (Eleusine coracana) can add substantial value to the diet in terms of protein and carbohydrates which is comparable to other cereals. In addition it contributes vitamins, minerals and fiber as it is consumed whole, in comparison to rice which is usually consumed after milling and polishing (Malleshi \& Hadimani, 1993).

Dietary fibers in foods are beneficial for good health. Physiological impacts of insufficient dietary fiber intake are constipation, increased risk of coronary heart disease, and increased fluctuation of blood glucose and insulin levels (Jenkins, Kendall, \& Ransom, 1998; American Association of Cereal Chemists [AACC], 2001). 
Dietary fiber is largely composed of complex carbohydrates that are somewhat resistant to digestion. Soluble polysaccharides may undergo some metabolism in the small intestine and especially in the large intestine through bacterial enzymes, converting it to products that contribute to maintaining the colonic microflora, which is beneficial to digestion (Cummings, Southgate, Branch, \& Wiggins, 1979; Holloway, Tasman-Jones, \& Maher, 1983; Weisburger et al., 1993). Insoluble fiber like cellulose, found in plant cell walls, can aid in waste and toxin removal through several mechanisms (Weisburger et al., 1993).

Limited information on the nutritional value of the finger millet grown in the oasis of Gabes is available. Hence, information on the composition of the finger millet could be useful for understanding it's health benefits and also for augmenting its utilization as a source of nutraceuticals. The present study was carried out to evaluate the nutritional quality, particularly with respect to minerals and fiber components, of the finger millet grown in the oasis of Gabes.

\section{Materials and Methods}

\subsection{Samples}

This study was conducted with 30 accessions of finger millet. The samples of the finger millet were randomly collected, at the same season, from 4 coastal oases of Gabes in the South-east of Tunisia (Table1).

Table 1. Accessions of Eleusine coracana L., their codes and their places of origin in Gabes oases

\begin{tabular}{ll}
\hline Oasis & Population \\
\hline Cheninni & $\mathrm{CH} 1, \mathrm{CH} 2, \mathrm{CH} 3, \mathrm{CH} 4, \mathrm{CH} 5, \mathrm{CH} 6, \mathrm{CH} 7, \mathrm{CH} 8, \mathrm{CH} 9, \mathrm{CH} 10, \mathrm{CH} 11$ \\
Echatt & $\mathrm{E} 1, \mathrm{E} 2, \mathrm{E} 3$ \\
Bouchamma & $\mathrm{B} 1, \mathrm{~B} 2, \mathrm{~B} 3, \mathrm{~B} 4$ \\
Ghannouch & $\mathrm{GH} 1, \mathrm{GH} 2, \mathrm{GH} 3, \mathrm{GH} 4, \mathrm{GH} 5, \mathrm{GH} 6, \mathrm{GH} 7, \mathrm{GH} 8, \mathrm{GH} 9, \mathrm{GH} 10, \mathrm{GH} 11, \mathrm{GH} 12$ \\
\hline
\end{tabular}

\subsection{Mineral Analysis}

For the determination of mineral content (sodium, potassium, and phosphorus), $10 \mathrm{~g}$ of each sample is heated at $105 \pm 5^{\circ} \mathrm{C}$, than $1 \mathrm{~g}$ of each dry sample was incinerated during $4 \mathrm{~h}$ at $550^{\circ} \mathrm{C}$. Ashes were mixed with $4 \mathrm{ml}$ of distilled water and $1 \mathrm{ml}$ of concentrated $\mathrm{HCl}$. The solution was heated until boiling, then filtered and adjusted to $100 \mathrm{ml}$ with distilled water. The sodium and potassium contents were determined with a Sherwood 410 flame photometer regulated on the filter of sodium or potassium. The contents of sodium $\left(\% \mathrm{Na}^{+}\right)$or of potassium $(\%$ $\left.\mathrm{K}^{+}\right)$in the dry matter plant were calculated as: $\% \mathrm{Na}^{+}$or $\% \mathrm{~K}^{+}=(\mathrm{C} * \mathrm{DF}) /(100 * \mathrm{~m})$, where $\mathrm{C}$ is the concentration of sodium or potassium $(\mathrm{mg} / \mathrm{l}), \mathrm{DF}$ is the factor of dilution and $\mathrm{m}$ is the mass of the extract $(\mathrm{g})$. The phosphorus concentration was determined using a Secomam spectrophotometer. Standard solutions of P 0, $2,4,8 \mathrm{mg} / 1$ were prepared by diluting basic solution of $\mathrm{P} 100 \mathrm{mg} / \mathrm{l}$ and $10 \mathrm{ml}$ of each standard and the diluted extract were placed in $25 \mathrm{ml}$ tubes with $10 \mathrm{ml}$ of the vanadomolybdic reagent $(200 \mathrm{ml}$ of $10 \%$ ammonium heptamolybdate solution obtained with dissolving $100 \mathrm{~g}$ of ammonium heptamolybdate in $10 \mathrm{ml}$ of ammonium hydroxide and adding distilled water until volume of 1 liter; $200 \mathrm{ml}$ of ammonium monovanadate solution obtained with $2.35 \mathrm{~g}$ of ammonium monovanadate in $400 \mathrm{ml}$ of hot distilled water, $20 \mathrm{ml}$ of $35 \%$ diluted nitric acid and distilled water until 1liter, $135 \mathrm{ml}$ of concentrated nitric acid and distilled water until 1liter). After 10 $\min$, the absorbances were measured at $430 \mathrm{~nm}$. Extracts were diluted if needed. P concentrations were calculated with the formula: \% $\mathrm{P}=(\mathrm{C} \times \mathrm{DF}) /(100 \mathrm{x} \mathrm{m})$, where $\mathrm{C}: \mathrm{P}$ content $(\mathrm{mg} / \mathrm{l})$, DF Dilution factor, $\mathrm{m}$ extract mass $(\mathrm{g})$. Nitrogen $(\mathrm{N})$ content was measured by the Kjeldahl method. It consists on an attack of $0.5 \mathrm{~g}$ of a sample (in a digestion tube) by the concentrated sulfuric acid in the presence of a catalyst $\left(58.75 \mathrm{~g}\right.$ of $\mathrm{Na}_{2} \mathrm{SO}_{4}$ and $1 \mathrm{~g}$ of $\mathrm{CuSO}_{4}$ ). The tube containing the sample is placed in the still of type "Vapodest". The concentrated $\mathrm{NaOH}$ is pumped to the sample where $\mathrm{NH}_{4}$ is transformed to $\mathrm{NH}_{3}{ }^{+}$. The $\mathrm{NH}_{3}$ is then driven by the vapor into a vessel containing the Boric acid. The solution becomes green. Finally, the distillate is titrated with a solution of $\mathrm{HCl}(0.01 \mathrm{~N})$ until the green color becomes violet. The $\mathrm{CP}$ was calculated as $\mathrm{N}^{*} 6.25$.

\subsection{Fiber Analysis}

Dietary fiber in finger millet samples was analyzed using an Ankom ${ }^{220}$ Fiber Analyzer (ANKOM Technology, Fairport, NY). The contents of crude fiber (CF), acid-detergent fiber (ADF) and neutral-detergent fiber (NDF) were sequentially determined in the Ankom ${ }^{220}$ Fiber Analyzer using Ankom filter bags F57 (Van Soest, Robertson, \& Lewis, 1991; Goering \& Van Soest, 1970). 
Briefly, the samples were hydrolyzed in filter bags (F57 ANKOM Technology) by using $\mathrm{H}_{2} \mathrm{SO}_{4}$ and $\mathrm{NaOH}$ separately, $45 \mathrm{~min}$ (for CF); cetyl trimethyl ammonium bromide (ADF Solution), 60 min (for ADF); sodium lauryl sulphate (NDF Solution), $75 \mathrm{~min}$ (for NDF). Then, the filter bags containing the samples were washed in water (three times) and in acetone (once, $3 \mathrm{~min})$. After acetone evaporation, the bags were dried at $105^{\circ} \mathrm{C}(4 \mathrm{~h})$ and then incinerated in a muffle furnace at $550^{\circ} \mathrm{C}(5 \mathrm{~h})$. Percentages of NDF, ADF and CF were calculated taking into account the weights of the bag, the sample and residues after digestion.

\subsection{Statistical Analysis}

For each of the chemical elements, a one-way variance analysis (ANOVA) was performed to compare the variations between the studied accessions using SPSS 16.0 software (SPSS Inc., Chicago, IL, USA). Data were expressed as mean \pm standard error. A hierarchical classification analysis, based on mineral, fiber, protein and ash contents variations between the accessions, was carried out using Ward's method. Correlations between different parameters were established using the test of Pearson.

\section{Results}

\subsection{Mineral Content}

The mineral analysis revealed significant variations between the accessions studied, in the grain nutrients $(\mathrm{p}<0.05)$. As represented in the table 2, the sodium content varied from 13.73 (GH5) to $42.47 \mathrm{mg} / 100 \mathrm{~g}(\mathrm{CH} 7)$. The potassium content varied from 11.24 (GH7) to $284.7 \mathrm{mg} / 100 \mathrm{~g}$ (CH7). The Calcium content varied from 189.93 (GH4) to $1272.36 \mathrm{mg} / 100 \mathrm{~g}$ (GH9). The magnesium content varied from 84.71 (GH4) to $567.45 \mathrm{mg} / 100 \mathrm{~g}$ (GH9). The nitrogen content varied from 0.31 (GH7) to $1.9 \%$ (GH9). The phosphorus content varied from 2.208 (GH7) to $11.033 \mathrm{mg} / 100 \mathrm{~g}$ (CH1).

Table 2. Mineral composition of the finger millet of some oasis of Gabes

\begin{tabular}{|c|c|c|c|c|c|c|}
\hline & $\mathrm{Na}^{+}(\mathrm{mg} / 100 \mathrm{~g})$ & $\mathrm{K}^{+}(\mathrm{mg} / 100 \mathrm{~g})$ & $\mathrm{P}(\mathrm{mg} / 100 \mathrm{~g})$ & $\mathrm{Ca}(\mathrm{mg} / 100 \mathrm{~g})$ & $\mathrm{Mg}(\mathrm{mg} / 100 \mathrm{~g})$ & $\% \mathrm{~N}$ \\
\hline $\mathrm{CH} 1$ & $32.50 \pm 1.13$ & $231.4 \pm 59.57$ & $11.03 \pm 1.62$ & $302.41 \pm 27.84$ & $134.87 \pm 12.41$ & $1.40 \pm 0.00$ \\
\hline $\mathrm{CH} 2$ & $25.14 \pm 1.18$ & $26.29 \pm 3.39$ & $3.08 \pm 0.31$ & $331.92 \pm 73.18$ & $148.03 \pm 32.63$ & $0.66 \pm 0.006$ \\
\hline $\mathrm{CH} 3$ & $32.43 \pm 1.12$ & $193.7 \pm 21.47$ & $10.66 \pm 1.42$ & $298.72 \pm 29.27$ & $133.22 \pm 13.05$ & $0.88 \pm 0.001$ \\
\hline $\mathrm{CH} 4$ & $20.7 \pm 1.79$ & $27.52 \pm 6.88$ & $4.45 \pm 1.66$ & $269.22 \pm 44.71$ & $120.07 \pm 19.94$ & $1.33 \pm 0.005$ \\
\hline $\mathrm{CH} 5$ & $38.93 \pm 0.25$ & $240.5 \pm 68.70$ & $7.93 \pm 0.68$ & $389.08 \pm 24.94$ & $173.52 \pm 11.12$ & $0.82 \pm 0.002$ \\
\hline CH6 & $29.59 \pm 0.26$ & $204.1 \pm 21.47$ & $9.1 \pm 0.60$ & $413.05 \pm 27.84$ & $184.21 \pm 12.41$ & $0.84 \pm 0.004$ \\
\hline $\mathrm{CH} 7$ & $42.47 \pm 1.74$ & $284.7 \pm 66.52$ & $7.9 \pm 0.95$ & $309.79 \pm 41.75$ & $138.16 \pm 18.62$ & $0.86 \pm 0.58$ \\
\hline $\mathrm{CH} 8$ & $34.57 \pm 0.95$ & $259.69 \pm 78.37$ & $9.46 \pm 0.50$ & $350.36 \pm 42.25$ & $156.25 \pm 18.84$ & $0.88 \pm 0.00$ \\
\hline $\mathrm{CH} 9$ & $28.59 \pm 2.74$ & $188.5 \pm 64.12$ & $8.53 \pm 0.63$ & $516.32 \pm 42.25$ & $230.27 \pm 18.84$ & $0.72 \pm 0.001$ \\
\hline E1 & $29.82 \pm 4.60$ & $172.9 \pm 51.49$ & $3.3 \pm 0.27$ & $359.58 \pm 126.75$ & $160.36 \pm 56.53$ & $0.91 \pm 0.52$ \\
\hline E2 & $28.59 \pm 1.95$ & $228.8 \pm 63.04$ & $5.03 \pm 1.18$ & $654.62 \pm 69.60$ & $291.95 \pm 31.04$ & $0.92 \pm 0.00$ \\
\hline E3 & $30.74 \pm 3.22$ & $217.1 \pm 44.86$ & $3.85 \pm 0.30$ & $331.92 \pm 110.64$ & $148.03 \pm 49.34$ & $0.52 \pm 0.35$ \\
\hline B1 & $37.72 \pm 3.82$ & $149.5 \pm 29.78$ & $3.27 \pm 0.44$ & $313.48 \pm 84.50$ & $139.80 \pm 37.68$ & $0.69 \pm 0.31$ \\
\hline B2 & $27.50 \pm 4.62$ & $208 \pm 49.38$ & $3.68 \pm 1.52$ & $276.6 \pm 82.98$ & $123.36 \pm 37.00$ & $0.63 \pm 0.007$ \\
\hline B3 & $25.13 \pm 2.92$ & $24.02 \pm 2.50$ & $2.79 \pm 0.31$ & $276.6 \pm 55.32$ & $123.36 \pm 24.67$ & $0.94 \pm 0.005$ \\
\hline B4 & $29.93 \pm 0.83$ & $158.6 \pm 23.50$ & $4.78 \pm 0.10$ & $320.85 \pm 39.89$ & $143.09 \pm 17.79$ & $0.97 \pm 0.01$ \\
\hline GH1 & $28.50 \pm 8.39$ & $248.69 \pm 46.82$ & $3.10 \pm 0.87$ & $221.28 \pm 55.32$ & $98.68 \pm 24.67$ & $1.10 \pm 0.009$ \\
\hline $\mathrm{GH} 2$ & $33.81 \pm 8.55$ & $252.46 \pm 119.47$ & $3.35 \pm 0.18$ & $239.72 \pm 42.25$ & $106.91 \pm 18.84$ & $0.86 \pm 0.003$ \\
\hline GH3 & $34.63 \pm 10.67$ & $12.40 \pm 6.93$ & $3.11 \pm 0.38$ & $350.36 \pm 42.25$ & $156.25 \pm 18.84$ & $0.12 \pm 0.002$ \\
\hline GH4 & $18.26 \pm 4.13$ & $31.25 \pm 2.53$ & $3.6 \pm 0.95$ & $189.93 \pm 28.38$ & $84.70 \pm 12.66$ & $0.79 \pm 0.007$ \\
\hline GH5 & $13.73 \pm 1.58$ & $24.34 \pm 4.75$ & $3.46 \pm 1.24$ & $590.08 \pm 42.25$ & $263.16 \pm 18.84$ & $0.47 \pm 0.01$ \\
\hline GH6 & $25.60 \pm 3.36$ & $18.42 \pm 3.49$ & $3.28 \pm 0.52$ & $719.16 \pm 27.66$ & $320.73 \pm 12.33$ & $0.82 \pm 0.12$ \\
\hline GH7 & $18.51 \pm 1.83$ & $11.24 \pm 2.22$ & $2.20 \pm 0.03$ & $237.87 \pm 41.76$ & $106.08 \pm 18.62$ & $0.31 \pm 0.007$ \\
\hline GH8 & $19.20 \pm 1.63$ & $69.31 \pm 16.85$ & $3.66 \pm 0.27$ & $1097.18 \pm 97.13$ & $489.32 \pm 43.32$ & $0.92 \pm 0.004$ \\
\hline GH9 & $19.47 \pm 1.31$ & $46.95 \pm 8.55$ & $3.18 \pm 0.37$ & $1272.36 \pm 110.64$ & $567.45 \pm 49.34$ & $1.90 \pm 0.01$ \\
\hline $\mathrm{CH} 10$ & $28.44 \pm 13.04$ & $21.26 \pm 5.64$ & $3.21 \pm 0.36$ & $368.8 \pm 42.25$ & $164.48 \pm 18.84$ & $1.08 \pm 0.002$ \\
\hline CH11 & $20.77 \pm 1.56$ & $21.99 \pm 10.41$ & $3.34 \pm 0.56$ & $665.68 \pm 110.68$ & $296.88 \pm 49.36$ & $0.41 \pm 0.00$ \\
\hline GH10 & $37.88 \pm 11.56$ & $243.1 \pm 50.74$ & $3.55 \pm 1.29$ & $285.82 \pm 69.60$ & $127.47 \pm 31.04$ & $1.13 \pm 0.007$ \\
\hline GH11 & $31.42 \pm 2.08$ & $111.8 \pm 25.37$ & $3.48 \pm 0.03$ & $341.14 \pm 57.57$ & $152.14 \pm 25.67$ & $1.12 \pm 0.007$ \\
\hline GH12 & $31.81 \pm 3.22$ & $208 \pm 51.49$ & $3.30 \pm 0.25$ & $212.06 \pm 15.96$ & $94.57 \pm 7.12$ & $0.98 \pm 0.17$ \\
\hline
\end{tabular}

Values are mean \pm standard deviation. 


\subsection{Protein and Ash Content}

The protein and the ash contents analysis showed a very highly significant variation between the accessions studied. The Figure 1 reveal that, the protein content varied from 0.78 (GH3) to $11.88 \%(\mathrm{GH} 9)$. The ash content varied from 2.77 (GH3) to $3.86 \%$ (B2).

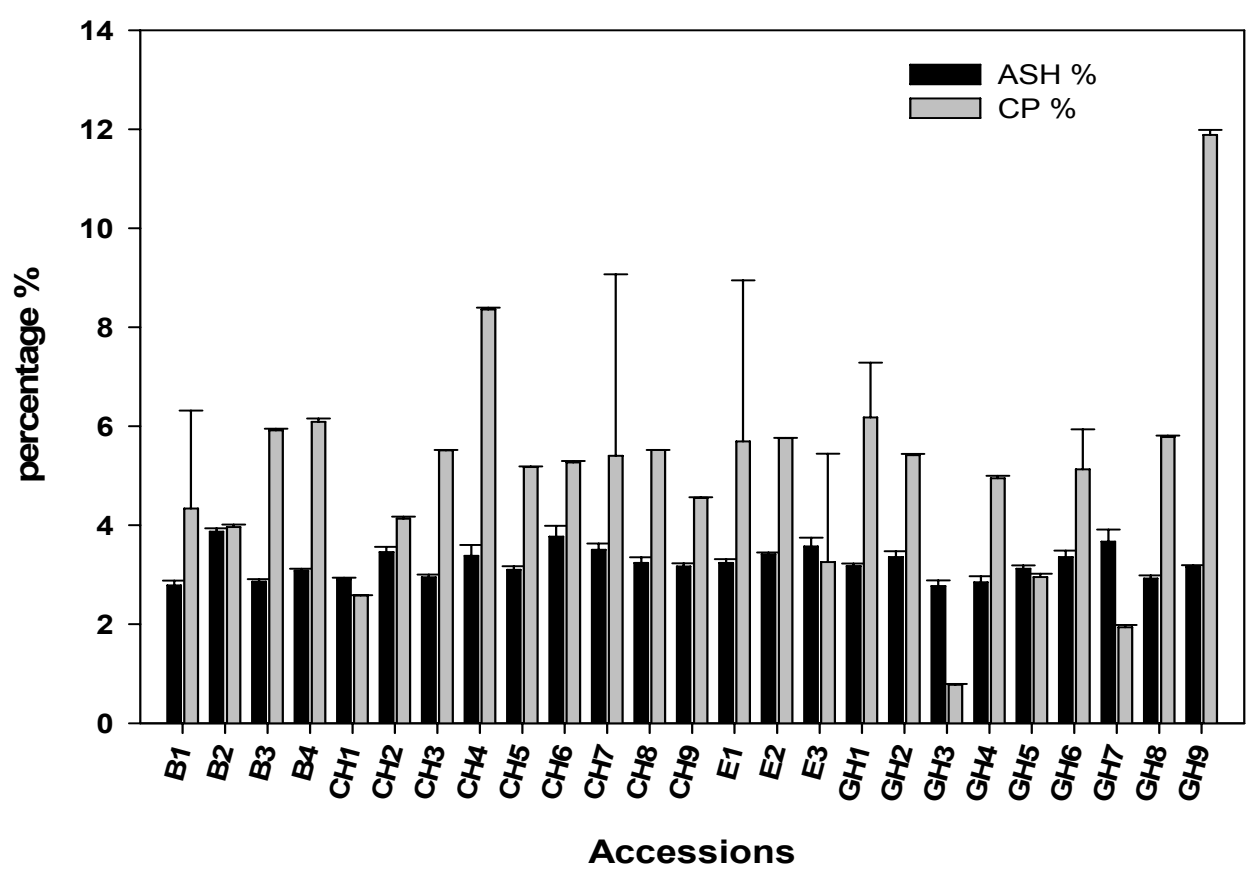

Figure 1. Protein and Ash content of the finger millet of some oasis of Gabes

\subsection{Fiber Content}

The Dietary fiber analysis showed a very highly significant variation in the fiber content between the accessions studied. As showed in Table 3, the NDF content varied from 22.92 (GH1) to $57.25 \%$ of DM (GH11). The ADF content varied from 14.79 (CH9) to $10.67 \%$ of DM (GH3). The crude fiber content varied from 0.93 (CH10) to $10.01 \%$ (GH11).

\subsection{Chemical Structure}

The hierarchical classification, based on mineral, fiber, protein and ash contents structured the studied accessions in three groups (Figure 2). The first group was consisted of 20 accessions characterized by the highest levels of $\mathrm{Na}^{+}(30.37 \mathrm{mg} / 100 \mathrm{~g}), \mathrm{K}^{+}(155.28 \mathrm{mg} / 100 \mathrm{~g}), \mathrm{P}(5.11 \mathrm{mg} / 100 \mathrm{~g})$, NDF (31.23\%), CF (4.19\%), and Ash (3.22\%). The second group held 2 accessions (GH8 and GH9) characterized by the highest levels of $\mathrm{Ca}^{2+}(1184.77$ $\mathrm{mg} / 100 \mathrm{~g}), \mathrm{Mg}^{2+}(528.39 \mathrm{mg} / 100 \mathrm{~g}), \mathrm{CP}(8.83 \%)$ and $\mathrm{ADF}(12.82 \%)$. The third group was composed by 4 accessions (CH11, GH5, GH6 and E2) characterized by the lowest levels of $\mathrm{N}(0.65 \%), \mathrm{CP}(4.1 \%)$, NDF (27.95\%), $\mathrm{ADF}(12.12 \%)$ and $\mathrm{CF}(3.23 \%)$.

A positive correlation was found between the sodium content and the potassium (0.72) and the phosphorus $(0.42)$ contents. Meanwhile the correlation between the sodium and the calcium content was negative $(-0.42)$. A positive correlation was also found between the potassium and the phosphorus content $(0.55)$.

The correlations between the NDF and the $\mathrm{ADF}(0.43)$ and the crude fiber ( 0.59$)$ contents were also positive. 
Table 3. Dietary fibers composition (\% dry basis) of the 30 accessions studied of the Finger millet

\begin{tabular}{|c|c|c|c|}
\hline & $\%$ NDF & $\%$ ADF & $\% \mathrm{CF}$ \\
\hline $\mathrm{CH} 1$ & $34.20 \pm 0.01$ & $12.27 \pm 0.03$ & $4.00 \pm 0.08$ \\
\hline $\mathrm{CH} 2$ & $31.26 \pm 0.04$ & $12.26 \pm 0.05$ & $3.57 \pm 0.01$ \\
\hline $\mathrm{CH} 3$ & $31.41 \pm 0.01$ & $12.62 \pm 0.05$ & $3.34 \pm 0.008$ \\
\hline $\mathrm{CH} 4$ & $35.11 \pm 0.09$ & $13.17 \pm 0.02$ & $3.72 \pm 0.005$ \\
\hline $\mathrm{CH} 5$ & $31.86 \pm 0.02$ & $14.05 \pm 0.03$ & $5.04 \pm 0.02$ \\
\hline CH6 & $33.19 \pm 0.007$ & $13,85 \pm 0.01$ & $6,78 \pm 0.008$ \\
\hline $\mathrm{CH} 7$ & $30.60 \pm 0.05$ & $12,57 \pm 0.02$ & $9,06 \pm 0.02$ \\
\hline $\mathrm{CH} 8$ & $27.40 \pm 0.01$ & $12.67 \pm 0.02$ & $3.67 \pm 0.01$ \\
\hline CH9 & $28.21 \pm 0.10$ & $14.79 \pm 0.17$ & $4.95 \pm 0.01$ \\
\hline $\mathrm{CH} 10$ & $24.21 \pm 0.10$ & $10.83 \pm 0.04$ & $0.93 \pm 0.007$ \\
\hline $\mathrm{CH} 11$ & $31.07 \pm 0.10$ & $11.47 \pm 0.02$ & $3.65 \pm 0.01$ \\
\hline E1 & $26.48 \pm 0.06$ & $13.05 \pm 0.04$ & $3.06 \pm 0.01$ \\
\hline E2 & $27.06 \pm 0.05$ & $11.77 \pm 0.008$ & $2.96 \pm 0.03$ \\
\hline E3 & $35.34 \pm 0.08$ & $12.12 \pm 0.008$ & $3.16 \pm 0.03$ \\
\hline B1 & $25.66 \pm 0.10$ & $11.95 \pm 0.06$ & $3.67 \pm 0.005$ \\
\hline B2 & $40.70 \pm 0.14$ & $11.85 \pm 0.03$ & $3.24 \pm 0.02$ \\
\hline B3 & $23.83 \pm 0.38$ & $12.33 \pm 0.005$ & $3.59 \pm 0.006$ \\
\hline B4 & $23.58 \pm 0.02$ & $12.58 \pm 0.02$ & $3.86 \pm 0.01$ \\
\hline GH1 & $22.92 \pm 0.05$ & $11.21 \pm 0.003$ & $3.56 \pm 0.007$ \\
\hline GH2 & $25.56 \pm 0.38$ & $13.00 \pm 0.003$ & $3.81 \pm 0.006$ \\
\hline GH3 & $26.18 \pm 0.13$ & $10.67 \pm 0.01$ & $3.09 \pm 0.01$ \\
\hline GH4 & $34.29 \pm 0.32$ & $13.48 \pm 0.03$ & $3.88 \pm 0.005$ \\
\hline GH5 & $25.52 \pm 0.11$ & $11.58 \pm 0.02$ & $2.78 \pm 0.009$ \\
\hline GH6 & $28.16 \pm 0.04$ & $13.65 \pm 0.01$ & $3.52 \pm 0.009$ \\
\hline GH7 & $30.67 \pm 0.40$ & $13.98 \pm 0.008$ & $3.21 \pm 0.005$ \\
\hline GH8 & $27.52 \pm 0.06$ & $12.88 \pm 0.005$ & $3.25 \pm 0.04$ \\
\hline GH9 & $28.39 \pm 0.24$ & $12.75 \pm 0.005$ & $3.81 \pm 0.02$ \\
\hline GH11 & $57.25 \pm 3.54$ & $14.61 \pm 0.77$ & $10.01 \pm 0.77$ \\
\hline GH12 & $35.38 \pm 1.19$ & $13.32 \pm 0.92$ & $3.63 \pm 0.03$ \\
\hline Total & $30,58 \pm 6.60$ & $12,65 \pm 1.03$ & $4,01 \pm 1.74$ \\
\hline
\end{tabular}

Values are mean \pm standard deviation.

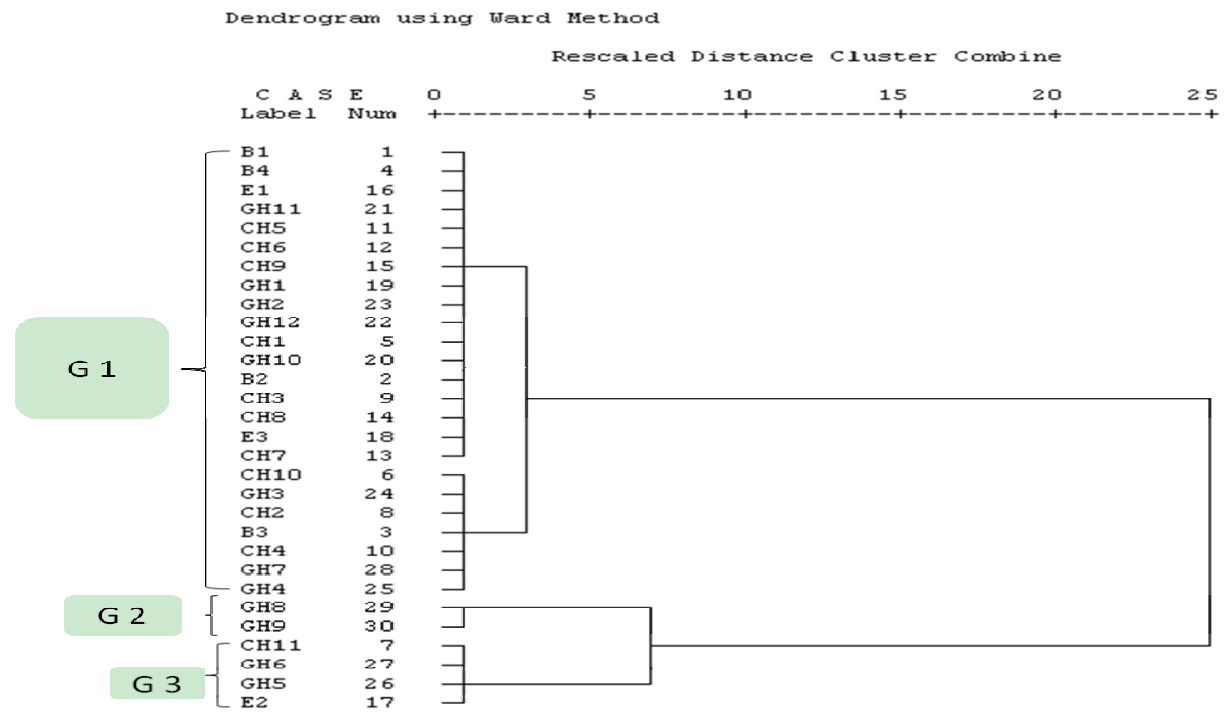

Figure 2. Cluster analysis of studied accessions according mineral, fiber, protein and ash contents G1: group 1, G2: group 2 and G3: group 3. 


\section{Discussion}

The finger millet is a good source of nutrients especially of calcium, other minerals and fiber (Singh \& Raghuvanshi, 2012). It's cultivation is in regression in the oases of Gabes. In order to encourage people to consume the finger millet, we wanted to assess the nutritional quality of the accessions of some oases of Gabes. The studied chemical characteristics showed considerable variations between accessions for all of the contents. Singh and Raghuvanshi (2012) reported that the mineral composition of millet grains is highly variable. The genetic factors and environmental conditions prevailing in growing region affect the mineral content of these food grains.

The calcium average content of the prospected finger millets is $416.86 \mathrm{mg} / 100 \mathrm{~g}$ which is consistent with Vadivoo, Joseph and Garesan (1998) results where the calcium content of 36 genotypes of finger millet ranged from 162 to $487 \mathrm{mg} \%$ with mean value of $320.8 \mathrm{mg} \%$. Bhatt, Singh, Shrotria and Baskheti (2003) and Singh and Raghuvanshi (2012), reported that the finger has the highest calcium content among all cereals (344 mg/100g).

The phosphorous content varied from 2.208 (GH7) to $11.033 \mathrm{mg} / 100 \mathrm{~g}$ (CH1) with a mean value of 4.85 $\mathrm{mg} / 100 \mathrm{~g}$. These results are different with those found by Singh and Srivastava (2006) who reported that the finger millet phosphorus content's ranged from 130 to $295 \mathrm{mg} \%$ with a mean value of $180.43 \mathrm{mg} \%$

The protein is considered the second major component of millet. The protein content of the accessions studied varied from 0.78 (GH3) to $11.88 \%$ (GH9) with a mean of $5.43 \%$, which is consistent with the results sited by Singh and Raghuvanshi (2012) who reported that finger millet has nearly 7\% protein, but large variations in protein content from 5.6 to 12.70\% have been reported (Joshi \& Katoch, 1990; Ravindran, 1991; Rao, 1994; Marimurthu \& Rajagopalan, 1995; Antony, Sripriya, \& Chandra, 1996; Vadivoo et al., 1998; Mushtari Begum, 1998; Gautam, 2000; Sharma, 2001; Bhatt et al., 2003). Chethan and Malleshi (2007) reported that finger millet contains about $5-8 \%$ protein.

Saldivar (2003) also found that the finger millet protein content is $7.3 \%$ which is equivalent of that of Rice (7.5\%) but lower than that of the Wheat (14.4\%).

Total ash content is higher in finger millet than in commonly consumed cereal grains (Singh \& Raghuvanshi, 2012). In finger millet, the ash content has been found to be nearly 1.7 (Rao, 1994) to $4.13 \%$ (Rao, Mithyantha, Devi, \& Perur, 1973). This content correlates with the ash content of the studied accessions which varied from $2.77(\mathrm{GH} 3)$ to $3.86 \%$ (B2) with an average mean of $3.2 \%$. Results are also in correlation with those of Singh and Srivastava (2006) that showed that the total ash content of the sixteen varieties of finger millet they have studied ranged from 1.47 to $2.58 \%$ with a mean value of $2.11 \%$. Results are also consistent with those of Saldivar (2003) who showed that the finger millet ash content is $3 \%$, while that of the rice is $4.9 \%$ and that of the wheat is $1.9 \%$. Devi, Vijayabharathi, Sathyabama, Malleshi, and Priyadarisini (2011) reported also that the finger millet ash content is $3 \%$.

The NDF and the ADF contents of the accessions studied, varied from 22.92 (GH1) to $57.25 \%$ of DM (GH11) and from 14.79 (CH9) to $10.67 \%$ of DM (GH 3), respectively). ADF constituted about half the portion of NDF. Madibela and Modiakgotla (2004) reported that the NDF and the ADF content of the finger millet varied from 68.9 to $72.6 \% \mathrm{DM}$ and from 37.4 to $41.3 \% \mathrm{DM}$, respectively.

Those contents are higher than those of barley (ADF 7.5\%, NDF 24.1\%) reported by Marx (1999). They are also higher than those reported by Zilic et al. (2011) for the barely and the oat; the NDF was 24.84 and $15.16 \%$ DM, respectively and the $\mathrm{ADF}$ was 2.30 and $2.04 \% \mathrm{DM}$, respectively.

Cellulose forms the major portion of insoluble dietary fibre (Malleshi, Desikachar, \& Tharanthan, 1986). The crude fiber content varied from 0.93 (CH10) to $10.01 \%$ (GH11) in the accessions studied with a mean value of 4.01\%. Those results are near to those found by Devi et al. (2011), Joshi and Katoch (1990) and Kamath and Belavady (1980) who reported that the crude fiber content in the finger millet was $3.6 \%, 3.7 \%$ and $3.6 \%$ respectively. Saldivar (2003) reported $1.3 \%$ crude fiber in finger millet which is lowest than that of the rice $(10.2 \%)$ and wheat $(2.9 \%)$.

In conclusion, the studied accessions of the finger millet cultivated in the oases of Gabes, present an interesting variability in the different studied contents and most of them are comparable to the contents found in the finger millets cultivated worldwide. Thus, it should be noted that there is an interesting source of genetic diversity which needs to be better studied and preserved from the risk of extension for future breeding program. 


\section{References}

American Association of Cereal Chemists (AACC). (2001). The Definition of Dietary Fiber. Cereal Foods World, 46, 112-126.

Antony, U., Sripriya, G., \& Chandra, T. S. (1996). Effect of fermentation on the primary nutrients in finegr millet (Eleusine coracana). J. Agric. Food Chem., 44, 2616-2618. http://dx.doi.org/10.1021/jf950787q

Bennetzen, J. L., Dida, M. M., Manyera, N. W. M., \& Devos, K. M. (2003). Characterization of genetic diversity in finger millet (Eleusine coracana). Retrieved July 10, 2003, from http://www.cerealsgenomics.org/documents/BennetzenProp.doc

Bhatt, A., Singh, V., Shrotria, P. K., \& Baskheti, D. C. (2003). Coarse Grains of Uttaranchal: Ensuring sustainable Food and Nutritional Security. Indian Farmer's Digest (pp. 34-38).

Chethan, S., \& Malleshi, N. G. (2007). Finger millet polyphenols: optimization of extraction and the effect of pH on their stability. Food Chem., 105, 862-870. http://dx.doi.org/10.1016/j.foodchem.2007.02.012

Cummings, J. H., Southgate, D. A. T., Branch, W. J., \& Wiggins, H. S. (1979). The digestion of pectin in the human gut and its effect on calcium absorption and large bowel function. Br. J. Nutr., 41, 477-485. http://dx.doi.org/10.1079/BJN19790062

Devi, P. B., Vijayabharathi, R., Sathyabama, S., Malleshi, N. G., \& Priyadarisini, V. B. (2011). Health benefits of finger millet (Eleusine coracana L.) polyphenols and dietary fiber: a review. J. Food Sci Technol., 20.

Duke, J. A., \& Wain, K. K. (1981). Medicinal plants of the world. Computer index with more than 85,000 entries. 3 vols.

Gautam, R. (2000). Bole-bisrae motae anaaj. Kethi, 10, 14-17.

Goering, H. K., \& Van Soest, P. J. (1970). Forage fiber analysis (Apparatus, Reagents, Procedures, and some Applications). Agric. Handbook, No. 379. Washinton, DC: USDA-ARS.

Holloway, W. D., Tasman-Jones, C., \& Maher, K. (1983). Pectin digestion in humans. Am. J. Clin. Nut., 37, 253-255.

International Centre for Agricultural Research in the Semi Arid Tropics [ICRISAT]. (1997). Annual Report.

Jenkins, D. J. A., Kendall, C. W. C., \& Ransom, T. P. P. (1998). Dietary fiber, the evolution of the human diet and coronary heart disease. Nutr. Res, 18, 633-652. http://dx.doi.org/10.1016/S0271-5317(98)00050-5

Johnson, D. T. (1968). Finger millet-Rhodesia's neglected crop. Rhodesian Agricultural Journal, 65, 87-91.

Joshi, H. C., \& Katoch, K. K. (1990). Nutritive value of millets: A comparison with cereals and pseudocereals. Himalayan Res. Dev., 9, 26-28.

Kamath, M. V., \& Belavady, B. (1980). Unavailable carbohydrates of commonly consumed Indian foods. J. Sci. Food Agric., 31, 194-202. http://dx.doi.org/10.1002/jsfa.2740310211

Madibela, O. R., \& Modiakgotla, E. (2004). Chemical composition and in vitro dry matter digestibility of indigenous finger millet (Eleusine coracana) in Botswana. Livestock Research for Rural Development, 16(4), 2004.

Malleshi, N. G., \& Hadimani, N. A. (1993). Nutritional and technological characteristics of small millets and preparation of value added products from them. In K. W. Riley, S. C. Gupta, A. Seetharam, \& J. N. Mushong (Eds.), Advances in Small Millets (pp. 270-287). New Delhi: Oxford and IBH Publishing Company.

Malleshi, N. G., Desikachar, H. S. R., \& Tharanthan, R. N. (1986). Free sugars and non starchy polysaccharides of finger millet (Eleusine coracana), pearl millet (Pennisetum typhoides), foxtail millet (Steria italica) and their malts. Food chem., 20, 253-261. http://dx.doi.org/10.1016/0308-8146(86)90095-6

Marimurthu, R., \& Rajagopalan, R. (1995). Protein stability in ragi. Madras J., 82(11), 616-617.

Marx, T. A. H. (1999). Grain screening pellets for ruminants and evaluation of the 1996 NRC beef cattle nutrition model. M.Sc. Thesis. University of Saskatchewan, Saskatoon, SK.

Mushtari, B. J. (1998). Nutritive value of Ragi (Eleusine coracana Gaertn) before and after malting. Beverage Food World, 25(5), 38.

Rao, K. B., Mithyantha, M. S., Devi, L. S., \& Perur, N. G. (1973). Nutrient content of some new ragi varieties. Mysor J. Agric. Sci., 7, 562-565. 
Rao, P. U. (1994). Evaluation of protein quality of brown and white ragi (Eleusine coracana) before and after malting. Food Chem., 51, 433-436. http://dx.doi.org/10.1016/0308-8146(94)90198-8

Ravindran, G. (1991). Studies on millets: proximate composition, mineral composition, phytate, and oxalate contents. Food Chem., 39(1), 99-107. http://dx.doi.org/10.1016/0308-8146(91)90088-6

Saldivar, S. (2003). Cereals: dietary importance. In B. Caballero, L. Trugo, \& P. Finglas (Eds.), Encyclopedia of Food Sciences and Nutrition (pp. 1027-1033), Reino Unido: Academic Press, Agosto, London. http://dx.doi.org/10.1016/B0-12-227055-X/00190-5

Sharma, K. (2001). Bhaut kuch haat ke khayeega kal (pp. 448-455). Avishkar October.

Singh, P., \& Raghuvanshi, R. S. (2012). Finger millet for food and nutritional security.

Singh, P., \& Srivastava, S. (2006). Nutritional composition of sixteen new varieties of fingermillet. $J$. Community Mobilization Sustainable Dev., 1(2), 81-84.

Sripriya, G., Chandrashekharan, K., Murty, V. S., \& Chandra, T. S. (1996). ESR spectroscopic studies on free radical quenching action of finger millet (E. coracana). Food Chemistry, 57, 537-540. http://dx.doi.org/10.1016/S0308-8146(96)00187-2

Vadivoo, A. S., Joseph, R., \& Garesan, N. M. (1998). Genetic variability and calcium contents in finger millet (Eleusine coracana L.Gaertn) in relation to grain colour. Plant Foods Hum. Nutr., 52(4), 353-364. http://dx.doi.org/10.1023/A:1008074002390

Van Soest, P. J., Robertson, J. B., \& Lewis, B. A. (1991). Methods for dietary fiber, neutral detergente fiber, and non-starch polysacharides in relation to animal nutrition. J. Dairy Sci., 74, 3583-3589. http://dx.doi.org/10.3168/jds.S0022-0302(91)78551-2

Watt, J. M., \& Breyer-Brandwijk, M. G. (1962). The medicinal and poisonous plants of southern and eastern Africa (2nd ed). Edinburgh and London: E. \& S. Livingstone, Ltd..

Weisburger, J. H., Reddy, B. S., Rose, D. P., Cohen, L. A., Kendall, M. E., \& Wynder, E. L. (1993). Protective mechanisms of dietary fibers in nutritional carcinogenesis. Basic Life Sci., 61, 45-63.

Zilic, S., Dodig, D., Milašinovic šeremešic, M., Kandic, V., Kostadinovic, M., Prodanovic, S., \& Savic, D. (2011). Small grain cereals protein and dietary fibre content genetika, 43(2), 381-395. 